\title{
Hubungan Serapan N, P, dan K Tanaman Cabai terhadap Residunya di dalam Tanah yang Diberi Pupuk Cair Organik dengan NPK
}

\author{
Eso Solihin, Rija Sudirja, Maya Damayani dan Nadia Nuraniya Kamaludin \\ Departemen Ilmu Tanah dan Sumber Daya Lahan, Fakultas Pertanian, Universitas Padjadjaran \\ Jl. Raya Bandung Sumedang Km 21 Jatinangor \\ Alamat korespondensi: eso.solihin@unpad.ac.id
}

\begin{abstract}
The Relationship between N, P, and K Uptake of Chili Plants to Their Residues in Soil Treated by Liquid Organic Fertilizers and NPK
\end{abstract}

This study aims to determine the relationship of N, P, and K uptake of chili plants towards the residues in the soil treated with liquid organic fertilizer with the addition of inorganic fertilizers of N, P and K. The research was conducted from September 2017 to January 2018 in the experimental field and KTNT Laboratory, Faculty of Agriculture, Universitas Padjadjaran. The design used was simple complete randomized design with 10 treatments and were repeated 3 times, with the treatment arrangement as follows: $\mathrm{A}=$ Control $0 \mathrm{PS}+0 \mathrm{NPK}, \mathrm{B}=0 \mathrm{PCO}+1 \mathrm{NPK}, \mathrm{C}=1 \mathrm{PCO}+0$ $\mathrm{NPK}, \mathrm{D}=1 \mathrm{PCO}+1 / 4 \mathrm{NPK}, \mathrm{E}=1 \mathrm{PCO}+1 / 2 \mathrm{NPK}, \mathrm{F}=1 \mathrm{PCO}+3 / 4 \mathrm{NPK}, \mathrm{G}=1 \mathrm{PCO}+1 \mathrm{NPK}, \mathrm{H}=1 / 4$ $\mathrm{PCO}+3 / 4 \mathrm{NPK}, \mathrm{I}=1 / 2 \mathrm{PCO}+3 / 4 \mathrm{NPK}$ and $\mathrm{J}=3 / 4 \mathrm{PCO}+3 / 4 \mathrm{NPK}$. The results showed that the highest nutrient uptake and residue was found in the treatment of $1 \mathrm{PCO}+3 / 4$ NPK. Relationship between $\mathrm{N}, \mathrm{P}$ and $\mathrm{K}$ uptake with nutrient residue on the soil was detected. The $\mathrm{N}, \mathrm{P}$ and $\mathrm{K}$ residues were influenced by the N, P and K uptake of chili plants of $92 \%, 98 \%$, and $97 \%$, respectively.

Keywords: Chili, NPK, Liquid Organic Fertilizer, Residue, Absorption

\begin{abstract}
ABSTRAK
Penelitian ini bertujuan untuk mengetahui hubungan serapan N, P, dan K tanaman cabai terhadap residunya di dalam tanah yang diberi pupuk cair organik dengan pupuk anorganik $\mathrm{N}, \mathrm{P}$ dan $\mathrm{K}$. Penelitian dilaksanakan pada bulan September 2017 sampai dengan Januari 2018 di kebun percobaan dan Laboratorium KTNT Fakultas Pertanian, Universitas Padjadjaran. Rancangan yang digunakan adalah RAK sederhana dengan 10 perlakuan yang diulang 3 kali dengan susunan perlakuan sebagai berikut: $\mathrm{A}=$ Kontrol $0 \mathrm{PS}+0 \mathrm{NPK}, \mathrm{B}=0 \mathrm{PCO}+1 \mathrm{NPK}, \mathrm{C}=1 \mathrm{PCO}+0 \mathrm{NPK}, \mathrm{D}=$ $1 \mathrm{PCO}+1 / 4 \quad \mathrm{NPK}, \mathrm{E}=1 \mathrm{PCO}+1 / 2 \mathrm{NPK}, \mathrm{F}=1 \mathrm{PCO}+3 / 4 \mathrm{NPK}, \mathrm{G}=1 \mathrm{PCO}+1 \mathrm{NPK}, \mathrm{H}=1 / 4 \mathrm{PCO}+3 / 4$ $\mathrm{NPK}, \mathrm{I}=1 / 2 \mathrm{CO}+3 / 4 \mathrm{PK}$ dan $\mathrm{J}=3 / 4 \mathrm{PCO}+3 / 4 \mathrm{NPK}$. Hasil penelitian menunjukkan bahwa serapan dan residu hara tertinggi ialah perlakuan $\mathrm{F}=1 \mathrm{PCO}+3 / 4 \mathrm{NPK}$. Terdapat hubungan antara serapan $\mathrm{N}, \mathrm{P}$ dan $\mathrm{K}$ dengan residu hara pada tanah. Residu N, P dan $\mathrm{K}$ dipengaruhi oleh serapan $\mathrm{N}, \mathrm{P}$ dan $\mathrm{K}$ tanaman cabai masing-masing sebesar $92 \%$ serapan N, 98\% serapan $\mathrm{P}$, dan $97 \%$ serapan $\mathrm{K}$.
\end{abstract}

Kata Kunci: Cabai, NPK, PCO, Residu, Serapan

\section{PENDAHULUAN}

Unsur N, P, dan K merupakan unsur-unsur yang termasuk hara makro esensial bagi tanaman, termasuk cabai. Ketiganya berfungsi dalam proses metabolisme dan biokimia sel tanaman (Havlin et al., 2005). Nitrogen sebagai pembangun asam nukleat, protein, bioenzim, dan klorofil (Marschner, 1986). Fosfor sebagai pembangun asam nukleat, fosfolipid, bioenzim, protein, senyawa metabolik, dan merupakan bagian dari ATP yang penting dalam transfer energi (Uchida, 2000). Kalium mengatur keseimbangan ion-ion dalam sel, yang berfungsi dalam pengaturan berbagai mekanisme metabolik (Havlin et al., 2005). Pada umumnya tanaman cabai yang dibudidayakan memperoleh hara $\mathrm{N}, \mathrm{P}$, dan $\mathrm{K}$ dari pupuk anorganik dan pupuk organik. 
Penyerapan hara N, P, dan K oleh tanaman, dipengaruhi oleh ketersediaan haranya. Penyerapan hara oleh tanaman cabai terus terjadi selama tanaman masih memerlukan unsur hara ini untuk pertumbuhan dan perkembangan tanaman (Dubey et al., 2016). Sumber hara dari pupuk organik dapat diserap tanaman secara langsung dibandingkan pupuk organik yang memerlukan proses dekomposisi terlebih dahulu (bersifat slow release). Akan tetapi penggunaan pupuk anorganik secara intensif terlebih tanpa diimbangi dengan pupuk organik dapat meningkatkan residu yang secara perlahan menjadi penyebab kerusakan tanah, diantaranya tanah menjadi cepat mengeras, kurang mampu menyimpan air dan menurunkan $\mathrm{pH}$ tanah (Riley, 2015).

Pupuk Cair Organik (PCO) yang telah diformulasi, mengandung hara makro $\mathrm{N}, \mathrm{P}$, dan $\mathrm{K}$ dalam bentuk terlarut sehingga saat kontak dengan tanaman dapat langsung diserap sebagai hara tersedia. Manfaat lain PCO dapat mengurangi penggunaan pupuk anorganik NPK dan diharapkan dapat terus dimanfaatkan guna mengurangi residu pupuk anorganik yang menjadi salah satu pencemar tanah. Oleh karena itu, perlu diketahui hubungan antara jumlah hara yang diserap dengan residu untuk mengetahui efektivitas penyerapan juga dampaknya terhadap lingkungan. Dalam hal ini adalah terhadap tanah sehingga penelitian ini perlu dilikukan.

\section{BAHAN DAN METODE}

Penelitian ini terdiri atas kegiatan lapangan dan laboratorium. Kegiatan lapangan dilaksanakan di kebun milik petani Kabupaten Sumedang Jawa Barat. Kegiatan laboratorium yang terdiri atas analisis tanaman dan analisis tanah dilaksanakan di Laboratorium Kimia Tanah dan Nutrisi Tanaman, Fakultas Pertanian, Universitas Padjadjaran. Penelitian dilaksanakan pada bulan September 2017 sampai dengan Januari 2018. Bahan-bahan yang digunakan diantaranya pupuk anorganik: Urea (45\% N), SP-36 (36\% $\left.\mathrm{P}_{2} \mathrm{O}_{5}\right), \mathrm{KCl}\left(60 \% \mathrm{~K}_{2} \mathrm{O}\right)$, Pupuk Cair Organik hasil formulasi dengan kadar hara (Corganik $11,36 \%$, N-total 4,64\%, $\mathrm{P}_{2} \mathrm{O}_{5} 4,39 \%$ dan $\mathrm{K}_{2} \mathrm{O}$ $4,98 \%$ ), benih tanaman cabai varietas Unpad, media tanam (tanah Inceptisol), serta pestisida untuk pengendalian dan pemberantasan hama dan penyakit antara lain Decis 25 EC, Antracol 70 WP dan Furadan 3G. Rancangan percobaan menggunakan rancangan acak kelompok (RAK), sepuluh perlakuan dan tiga ulangan. Susunan perlakuan tertera pada Tabel 1 .

Tabel 1. Susunan perlakuan Pupuk Cair Organik dengan NPK terhadap tanaman cabai.

\begin{tabular}{|c|c|c|c|c|c|}
\hline \multirow{2}{*}{\multicolumn{2}{|c|}{ Perlakuan }} & PCO & Urea & SP-36 & $\mathrm{KCl}$ \\
\hline & & \multicolumn{4}{|c|}{----------------------------kg/ha------------------------ } \\
\hline 1 & A: Kontrol 0 PS + 0 NPK & 0 & 0 & 0 & 0 \\
\hline 2 & B: 0 PCO + 1 NPK & 0 & 150 & 200 & 150 \\
\hline 3 & C: 1 PCO + 0 NPK & 4 Liter & 0 & 0 & 0 \\
\hline 4 & D: $1 \mathrm{PCO}+1 / 4 \quad \mathrm{NPK}$ & 4 Liter & 37,5 & 50 & 37,5 \\
\hline 5 & E: 1 PCO + 1/2 NPK & 4 Liter & 75 & 100 & 75 \\
\hline 6 & F: $1 \mathrm{PCO}+3 / 4 \mathrm{NPK}$ & 4 Liter & 112,5 & 150 & 112,5 \\
\hline 7 & G: 1 PCO + 1 NPK & 4 Liter & 150 & 200 & 150 \\
\hline 8 & H: $1 / 4$ PCO + 3/4 NPK & 1 Liter & 112,5 & 150 & 112,5 \\
\hline 9 & I: $1 / 2$ PCO + 3/4 NPK & 2 Liter & 112,5 & 150 & 112,5 \\
\hline 10 & J: $3 / 4$ PCO + 3/4 NPK & 3 Liter & 112,5 & 150 & 112,5 \\
\hline
\end{tabular}

Keterangan: PCO = Pupuk Cair Organik, Kontrol = perlakuan tanpa N, P, dan K standar maupun PCO, Pupuk NPK standar = perlakuan pupuk organik anjuran untuk tanaman cabai manis (150 kg Urea, $200 \mathrm{~kg}$ SP-36 dan $150 \mathrm{~kg} \mathrm{KCl}$ per hektar)

Data yang diperoleh dari sampel-sampel tersebut selanjutnya dilakukan uji perbedaan pengaruh rata-rata perlakuan dengan uji $\mathrm{F}$ pada taraf $5 \%$ dan perbedaan rata-rata perlakuan yang diperoleh dilanjutkan dengan uji jarak berganda Duncan pada taraf 5\%. Parameter yang diamati dari sampel yang ditentukan terdiri atas pengamatan serapan hara Nitrogen, Fosfor dan Kalium pada jaringan tanaman serta residu yang ditinggalkan di dalam tanah. Untuk mengetahui hubungan serapan hara $\mathrm{N}, \mathrm{P}$ dan $\mathrm{K}$ dengan residu di dalam tanah dilakukan analisis regresi linier.

Pelaksanaan penelitian terdiri atas rangkaian dari kegiatan di lapangan maupun di 
laboratorium. Kegiatan di lapangan adalah mempersiapkan media tanam dilanjutkan dengan berbagai tahapan kegiatan penanaman mulai dari pesemaian, pindah tanam, dan pemeliharaan tanaman cabai hingga kegiatan sampling dan panen. Kegiatan di laboratorium dilakukan dengan menguji sampel yang diambil dari hasil percobaan di lapangan untuk mengetahui serapan dan residu hara $\mathrm{N}$, P dan $\mathrm{K}$ yang diberikan melalui PCO bersama pupuk standar.

\section{HASIL DAN PEMBAHASAN}

\section{Serapan N, P dan K}

Unsur makro yang diserap tanaman cabai dapat diketahui jumlahnya dari analisis jaringan tanaman. Kandungan hara tanaman cabai pada perlakuan tanpa Pupuk Cair Organik menunjukkan jumlah terendah meskipun tidak berbeda nyata dengan beberapa perlakuan. Untuk mengetahui efektivitas pemberian Pupuk Cair Organik terhadap kandungan hara $\mathrm{N}, \mathrm{P}$, dan $\mathrm{K}$ tanaman cabai dapat dilihat dari Gambar 1-3.

Serapan hara $\mathrm{N}$ tertinggi ditunjukkan oleh perlakuan $\mathrm{F}$ dan $\mathrm{G}$, yaitu perlakuan $1 \mathrm{PCO}+3 / 4 \mathrm{NPK}$ dan $1 \mathrm{PCO}+1$ NPK. Perlakuan 1 dosis PCO dengan berbegai perlakuan NPK dengan dosis yang dikurangi, menunjukkan hasil yang kurang baik dibandingkan dengan perlakuan pengurangan dosis PCO yang diaplikasikan bersama 1 dosis NPK. Perlakuan kontrol (tanpa pupuk) dan perlakuan PCO tanpa NPK menunjukkan hasil serapan $\mathrm{N}$ yang paling rendah. Hal ini karena suplay hara yang disediakan tanah kurang mencukupi dan tidak adanya tambahan hara $\mathrm{N}, \mathrm{P}$, dan $\mathrm{K}$ tersedia dari pupuk anorganik. Menurut Bernardinus dan Wiryanta (2002) pemberian pupuk pada tanaman adalah untuk menambah persediaan unsur hara yang dibutuhkan tanaman dalam meningkatkan produksi dan mutu hasil tanaman yang dihasilkan.

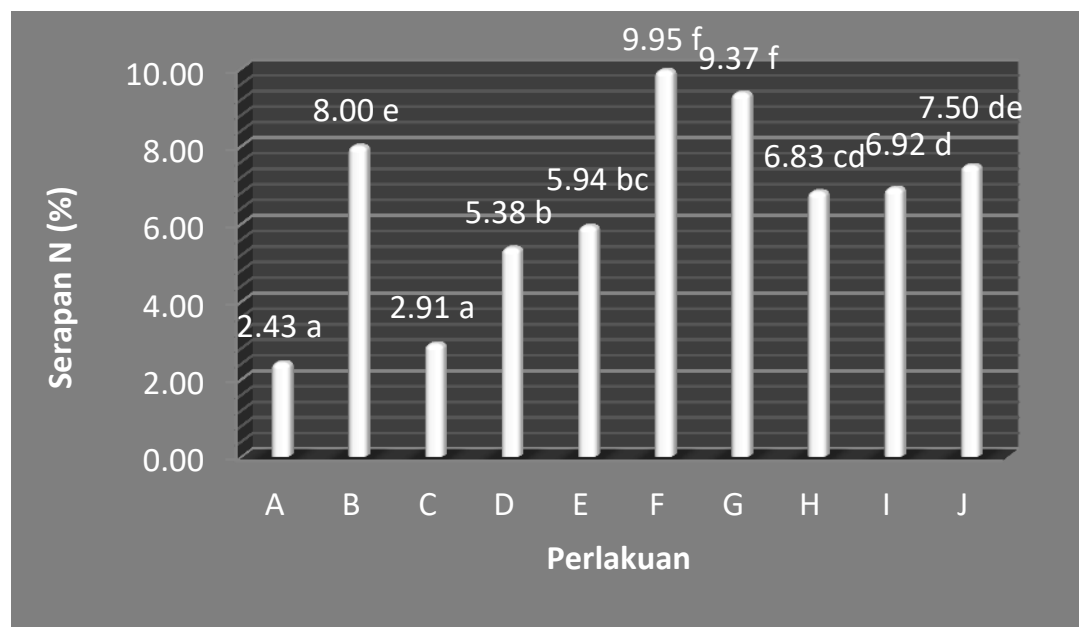

Gambar 1. Grafik pengaruh perlakuan terhadap serapan N.

Gambar 2 merupakan diagram yang menggambarkan hasil analisis statistik serapan $\mathrm{P}$ tanaman cabai. Terdapat kemiripan dengan serapan $\mathrm{N}$ bahwa penyerapan $\mathrm{P}$ tertinggi ditunjukkan oleh perlakuan F dan G, yaitu perlakuan $1 \mathrm{PCO}+3 / 4 \mathrm{NPK}$ dan 1 PCO + 1 NPK. Perlakuan PCO yang tidak diberikan bersama pupuk NPK menunjukkan hasil yang kurang baik meskipun analisis statistik signifikan dengan kontrol (tanpa pupuk).

Unsur P dalam tanah dan penyerapannya oleh tanaman sangat dipengaruhi oleh kondisi tanah, keadaan iklim dan kemampuan tanaman untuk menyerap hara dari tanah. Unsur P merupakan salah satu unsur yang harus disediakan sejak tahap awal pertumbuhan untuk memastikan pertumbuhan yang baik hingga fase akhir generatif. Tingginya serapan $\mathrm{P}$ pada perlakuan disebabkan oleh kontribusi $\mathrm{P}$ anorganik tanah yang berasal dari SP-36 serta serapan langsung melalui stomata akibat penyemprotan PCO. Selain itu, kondisi iklim mikro selama pertumbuhan tanaman cukup sesuai dengan syarat tumbuh tanaman cabai merah sehingga memungkinkan tanaman cabai dapat melakukan proses-proses fisiologisnya dengan baik dan proses penyerapan hara dapat berlangsung dengan baik. Serapan K pada Gambar 3 memiliki pola yang berbeda, serapan $\mathrm{K}$ perlakuan $\mathrm{C}$ dan $\mathrm{D}$ tidak signifikan dengan kontrol, sedangkan beberapa perlakuan menunjukkan notasi yang signifikan dibandingkan dengan kontrol. Serapan tertinggi ditunjukkan oleh perlakuan F. Akan tetapi seperti halnya serapan $\mathrm{N}$ dan $\mathrm{P}$, pada serapan $\mathrm{K}$ terlihat pula 
bahwa peran pupuk anorganik NPK masih sangat penting yang dibuktikan dengan rendahnya serapan $\mathrm{N}, \mathrm{P}$ dan $\mathrm{K}$ tanaman pada dosis pupuk NPK $0-1 / 2$ dosis. Hal ini karena unsur N, P dan K yang menjadi komponen menyusun PCO berjumlah sedikit.

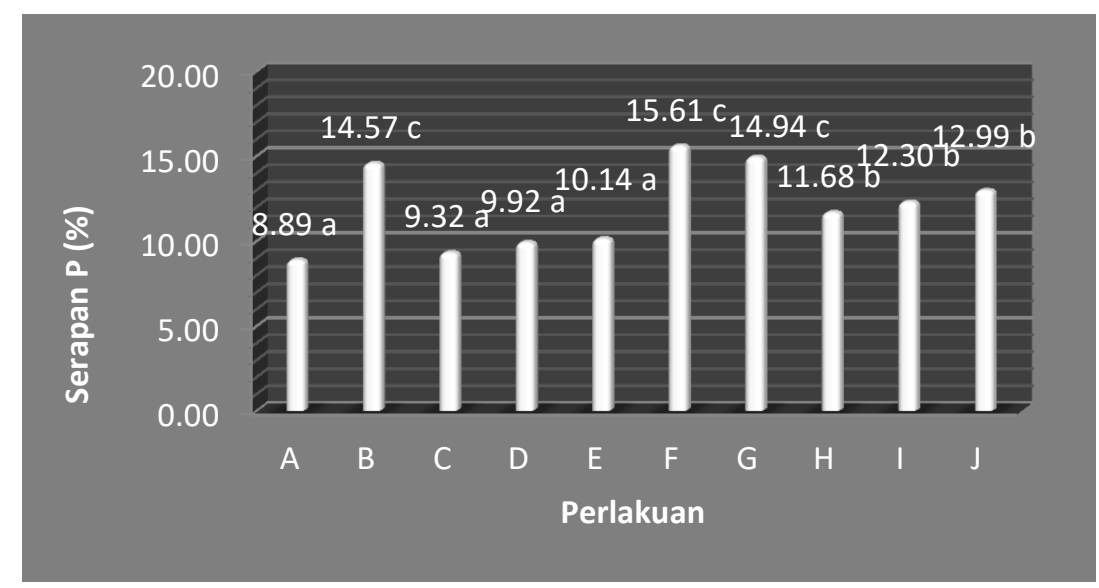

Gambar 2. Grafik pengaruh perlakuan terhadap serapan P.

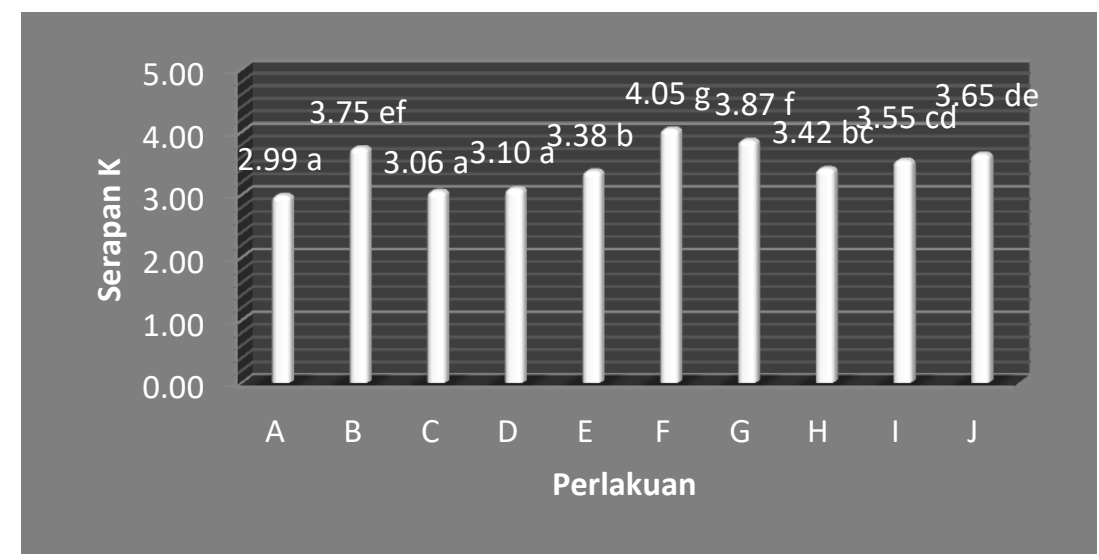

Gambar 3. Grafik pengaruh perlakuan terhadap serapan K.

\section{Kandungan N, P, dan K dalam Tanah}

Pemberian PCO secara tidak langsung juga berpengaruh terhadap kesuburan tanah dapat dilihat dari kandungan N-total, P-potensial, dan Kpotensial tanah sisa penyerapan yang berbeda nyata dengan kontrol (Tabel 2). Unsur hara N, P dan K tidak semuanya tersedia dan dapat diserap oleh tanaman sehingga perlu diketahui jumlah total atau jumlah dari potensi unsur tersebut. Unsur $\mathrm{N}$ merupakan unsur yang mobil dan mudah larut sehingga kehilangan unsur $\mathrm{N}$ akan sangat mudah. Menurut Habibi dan Elfarisna (2017), pupuk N umumnya sangat mobil dalam tanah sehingga bila pupuk nitrogen diberikan ke dalam tanah, maka harus dijaga dalam aplikasinya agar tidak mudah tercuci sebelum diserap oleh tanaman. $\mathrm{N}$ berada dalam betuk yang tersedia dan tidak tersedia bagi tanaman, hara ini sangat berpengaruh pada pertumbuhan tanaman sehingga dalam menanggulangi kehilangan unsur tersebut perlu diketahui jumlah $\mathrm{N}$-total yang ada di tanah.

Unsur P di dalam tanah terbagi kedalam P organik dan $\mathrm{P}$ anorganik, yang mana tanaman tidak dapat menyerap semua unsur $P$ yang ada di dalam tanah hanya $\mathrm{P}$ dalam bentuk tertentulah yang mampu diserap oleh tanaman. Unsur $\mathrm{P}$ diserap dalam bentuk ion $\mathrm{H}_{2} \mathrm{PO}_{4}^{-}$dan ion $\mathrm{HPO}_{4}{ }^{2-}$ (Safitri dkk., 2017). Fosfor merupakan penyusun senyawa transfer energi, sistem informasi genetik, merangasang pertumbuhan primordia bunga dan organ tanaman untuk reproduksi (Gardner dkk., 1991). Peranan lain unsur $P$ adalah pemasakan buah dan biji (Rosmarkam \& Yuwono, 2012). Pada unsur $\mathrm{K}$ pun demikian. Analisis yang dilakukan adalah melihat kandungan N-total, P-potensial dan Kpotensial pada tanah untuk setiap perlakuan aplikasi NPK dan PCO pada pertanaman cabai. Dengan demikian, pemberian PCO secara keseluruhan 
berdampak besar terhadap kesuburan kimia tanah. Pengaruh perlakuan terhadap keadaan kandungan $\mathrm{N}$-total tanah, P-potensial dan K-potensial tanah setelah panen.

Gambar 4 merupakan grafik yang menggambarkan hubungan serapan $\mathrm{N}$ terhadap residu $\mathrm{N}$ tanah, serapan $\mathrm{P}$ terhadap residu $\mathrm{P}$ tanah dan serapan $\mathrm{K}$ terhadap residu $\mathrm{K}$ tanah. Residu $\mathrm{N}$ tanah dipengaruhi oleh serapan $\mathrm{N}$ sebesar 92\%, residu $\mathrm{P}$ tanah dipengaruhi oleh serapan $\mathrm{P}$ sebesar 98\% dan $\mathrm{K}$ tanah sebesar $97 \%$ dipengaruhin serapan K. Hal ini karena dosis yang ditinggalkan sebagai residu setelah aplikasi akan dipengaruhi oleh sejumlah hara yang diserap oleh tanaman cabai.

Tabel 2. Residu N-total, P-potensial dan K-potensial tanah.

\begin{tabular}{lcccc}
\hline \multicolumn{1}{c}{ Perlakuan } & $\begin{array}{c}\text { N-total } \\
(\%)\end{array}$ & $\begin{array}{c}\text { P-potensial } \\
\left(\mathrm{mg} \mathrm{P} \mathrm{O}_{5} 100 / \mathrm{g}\right)\end{array}$ & $\begin{array}{c}\text { K-potensial } \\
(\mathrm{mg} \mathrm{K} 2 \mathrm{O} 100 / \mathrm{g})\end{array}$ \\
\hline $\mathrm{A}=$ Kontrol 0 PS + 0 NPK & $0,16 \mathrm{a}$ & $29,90 \mathrm{a}$ & $21,08 \mathrm{a}$ \\
$\mathrm{B}=0 \mathrm{PCO}+1 \mathrm{NPK}$ & $0,20 \mathrm{~cd}$ & $39,94 \mathrm{e}$ & $25,03 \mathrm{ef}$ \\
$\mathrm{C}=1 \mathrm{PCO}+0 \mathrm{NPK}$ & $0,17 \mathrm{ab}$ & $30,45 \mathrm{ab}$ & $21,38 \mathrm{ab}$ \\
$\mathrm{D}=1 \mathrm{PCO}+1 / 4 \mathrm{NPK}$ & $0,18 \mathrm{bc}$ & $30,96 \mathrm{ab}$ & $21,92 \mathrm{abc}$ \\
$\mathrm{E}=1 \mathrm{PCO}+1 / 2 \mathrm{NPK}$ & $0,20 \mathrm{~d}$ & $32,09 \mathrm{bc}$ & $23,54 \mathrm{cde}$ \\
$\mathrm{F}=1 \mathrm{PCO}+3 / 4 \mathrm{NPK}$ & $0,22 \mathrm{e}$ & $41,12 \mathrm{e}$ & 26,04 & $\mathrm{f}$ \\
$\mathrm{G}=1 \mathrm{PCO}+1 \mathrm{NPK}$ & $0,21 \mathrm{de}$ & $40,10 \mathrm{e}$ & $25,95 \mathrm{f}$ \\
$\mathrm{H}=1 / 4 \mathrm{PCO}+3 / 4 \mathrm{NPK}$ & $0,19 \mathrm{~cd}$ & $33,38 \mathrm{c}$ & $22,96 \mathrm{bcd}$ \\
$\mathrm{I}=1 / 2 \mathrm{PCO}+3 / 4 \mathrm{NPK}$ & $0,20 \mathrm{~cd}$ & $36,00 \mathrm{~d}$ & $23,97 \mathrm{de}$ \\
$\mathrm{J}=3 / 4 \mathrm{PCO}+3 / 4 \mathrm{NPK}$ & $0,20 \mathrm{~cd}$ & $37,45 \mathrm{~d}$ & $24,28 \mathrm{ef}$ \\
\hline
\end{tabular}

Keterangan: Angka-angka yang berhuruf sama tidak berbeda nyata menurut Uji Jarak Berganda Duncan pada taraf 5\%.
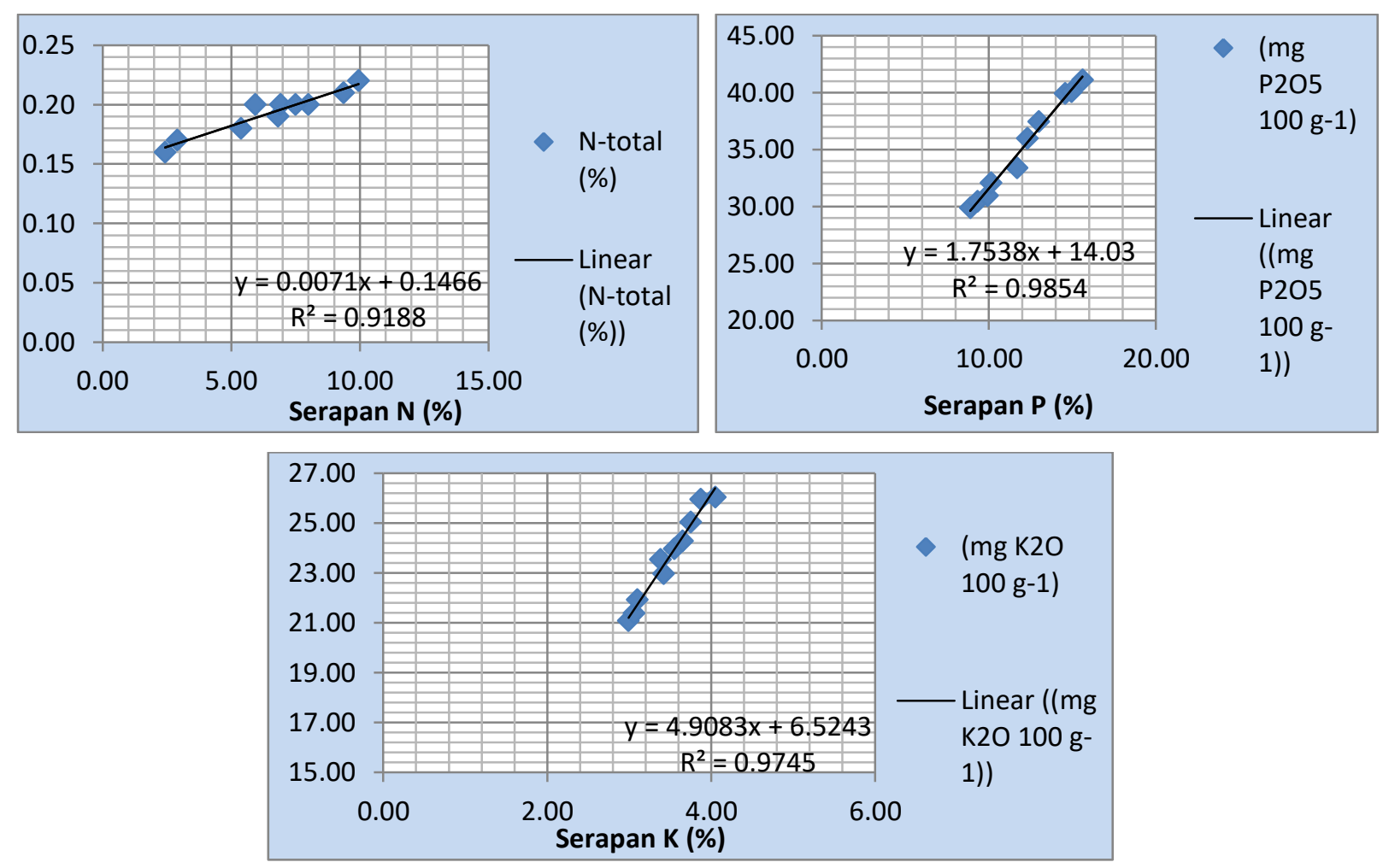

Gambar 4. Hubungan serapan terhadap residu N, P dan K. 


\section{SIMPULAN}

Pemberian PCO disertai pupuk NPK dapat meningkatkan serapan hara $\mathrm{N}, \mathrm{P}$ dan $\mathrm{K}$ tanaman cabai. Serapan $\mathrm{N}$ dan $\mathrm{P}$ tertinggi ditunjukkan oleh perlakuan F $(1 \mathrm{PCO}+3 / 4 \mathrm{NPK})$ dan G $(1 \mathrm{PCO}+1$ NPK) serta serapan $\mathrm{K}$ tertinggi pada perlakuan $\mathrm{F}$ (1 $\mathrm{PCO}+3 / 4 \mathrm{NPK})$. Sejumlah dosis yang diberikan pada masing-masing perlakuan memengaruhi residu hara $\mathrm{N}$, $\mathrm{P}$ dan $\mathrm{K}$ yang ditinggalkan dengan rata-rata residu $\mathrm{N}$ tertinggi ialah pada perlakuan $\mathrm{F}$, sedangkan $\mathrm{P}$ dan $\mathrm{K}$ tertinggi ialah pada perlakuan $\mathrm{F}$ dan $\mathrm{G}$. Hubungan serapan hara N, P, dan K tanaman cabai terhadap residu hara tersebut pasca pemanenan menunjukkan koefisien determinasi di atas 0,9 yang berarti bahwa $90 \%$ residu $\mathrm{N}, \mathrm{P}$ dan $\mathrm{K}$ dipengaruhi oleh tingkat penyerapan sejumlah hara yang diberikan.

\section{DAFTAR PUSTAKA}

Bernardinus, T, dan W Wiryanta. 2002. Bertanam Cabai pada Musim Hujan. AgroMedia Pustaka, Jakarta.

Dubey, AK, S Devi, SR Pranjal, K Yogesh, KV Ajay, and KC Sandip. 2016. Effect of NPK on plant growth, yield and quality of capsicum (Capsicum annum L.) under shade net condition. International Journal of Current Microbiology and Applied Sciences. 6(3): 1085-1091.

Gardner, FP, RB Pearce, dan RL Mitchell. 1991. Fisiologi Tanaman Budidaya. Penerjemah $\mathrm{H}$ Susilo., Universitas Indonesia Press, Jakarta.

Havlin, JL, JD Beaton, SL Tisdale, and WL Nelson. 2005. Soil Fertility and Fertilizers: An
Introduction to Nutrient Management. $7^{\text {th }}$ Ed. Pearson Prentice Hall, New Jersey.

Habibi, I, dan Elfarisna. 2017. Efisiensi pemberian pupuk organik cair untuk mengurangi penggunaan NPK terhadap tanaman cabai merah besar. Prosiding Seminar Nasional "Pertanian dan Tanaman Herbal Berkelanjutan di Indonesia”. Fakultas Pertanian UMJ. 8 November 2017. Hlm. 163-172.

Marschner, H. 1986. Mineral Nutrition of Higher Plants. 2 ${ }^{\text {nd }}$ Ed. Academic Press, San Diego, California.

Riley, H. 2015. Residual value of inorganic fertilizer and farmyard manure for crop yields and soil fertility after long-term use on a loam soil in Norway. Nutr Cycl Agroecosyst. 104: 25-37.

Rosmarkam, A, dan NA Yuwono. 2012. Ilmu Kesuburan Tanah. Kanisius, Yogyakarta.

Safitri, DA, R Linda, dan Rahmawati. 2017. Aplikasi Pupuk Organik Cair (POC) kotoran kambing difermentasikan dengan EM4 terhadap pertumbuhan dan produktivitas tanaman cabai rawit (Capsicum frutescents L.) var. Bara. Protobiont. 6(3): 182-187.

Uchida, R. 2000. Essential nutrients for plant growth: nutrient functions and deficiency symptoms. In Plant Nutrient Management in Hawaii's Soils, Approaches for Tropical and Subtropical Agriculture (J. A. Silva, R. Uchida, Eds.). College of Tropical Agriculture and Human Resources, University of Hawai at Manoa. 